談

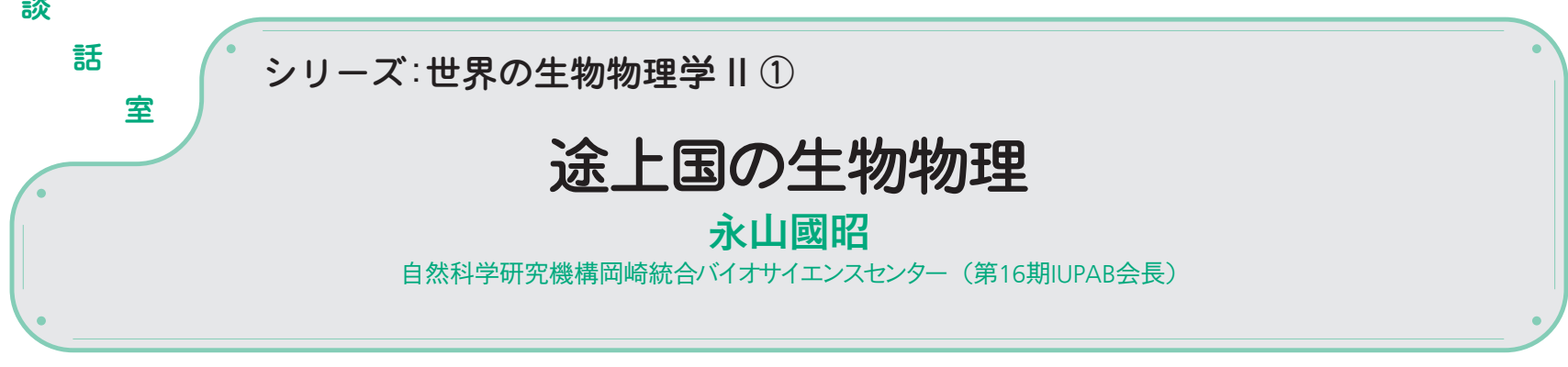

2007 年から 2008 年にかけ約 1 年半「世界の生物物 理学」を連載した ${ }^{1)}$. ABA (Asian Biophysics Association) のスタートを期に $\mathrm{ABA}$ 傘下のアジアの国々の生物物 理学会を紹介寸るのが主旨であった，今回は目をアジ アの外に向け世界の生物物理の現状を 3 回にわたって 紹介したい。初回は私が最近（2009年9月-10月） 訪机た発展途上国を中心に，2回目は先進的地域（欧 米）に焦点をあて，そして 3 回目は2011 年北京で開 催される第17回国際純粋・応用生物物理学連合 （IUPAB）大会に向けて大会の全体像を打伝えしたい.

20 日間の行程でイスラム圈の雄トルコ, 東欧の真 珠クロアチア，BRICsの一角ブラジルを訪れた（順不 同)。いずれもベルリンの壁崩壊以後の困難な政治情 勢を乗り越え，地域主体の国際的会議を開催できるほ ぞに安定期を迎えている国々である.

第 2 回国際生物物理学/バイオテクノロジー 大会（2009年10月 5 日-9日, トルコ）

チグリス川の上流はトルコ領であるとどのくらいの 日本人が知っているだろらか. そのチグリスの川辺に クルド語地帯の中心都市ディヤルバクルがある. 万里 の長城に次ぐ $6 \mathrm{~km}$ の城壁に囲屯れた落ち着いた古都 である、ローマ時代のコロセウムが今でも残り巨大さ を誇っている。その市の北方の乾いた原野に広大さを 誇るDicle大学が新設されつつある。ちなみに Dicle とはトルコ語でチグリス川を指す。その Dicle大とト ルコ生物物理学会の協催で今回の国際的学会が開かれ たのだが，18 年前に第 1 回が開かれたといらからや はりトルコの時間の流れはチグリス川の如くゆっくり している.

海外 10 力国近くから講演者が招待され（英国（4）, 米国（3），スペイン，ルーマニアなど)，28の招待講
演，50 の口頭発表，120 余のポスター発表が行われ た.トピックスは構造生物学, タンパク質フォール ディング，生体電磁気学，電気生理学，放射線物理と 多岐にわたっていた。私はIUPAB 会長として招かれ 初日の開会講演を行った。総じてトルコのレベルは日 本の 40 年前の生物物理学会を彷彿とさせる。すなわ ちきわめて大きなテーマたとえば脳の情報処理の探求 に脳波 1 本で挑むといらような，かつて乗り越えられ たパラダイムをいまだ踏襲している，欧米からの招待 講演とトルコからの口頭発表にはしたがって大きな ギャップが感じられた。 しかし若手の参加は大きな割 合を占め，彼らはそのレベル差をしっかり受け止めて いたよらに見える。何人かの若者につかまり，日本へ の留学の可能性を強く迫られた。何とか受入のシステ ムを作れればと思らのだがイスタンブール大のよらな トップクラスのトルコの大学が日本に顔を向けている とは思われない。ドイッをはじめとする西欧への移 民, 出稼ぎ数から考光，また EUの一角を切望する信 条から考光, トルコの生物物理のけん引役はやはり欧 州生物物理学連合（EBSA）に任すべきだろう。

いずれにせよクルド語地帯にも生物物理学に向から 多数の若者がいることを知り胸が熱くなった.

第 7 イベロアメリカ生物物理学大会 2009 (2009年10月30日-11月3日,リオデジャネイロ)

1990 年代以降の地勢学的動きにイベロアメリカと いら地域統合がある。スペイン，ポルトガルという旧 宗主国と中南米の結束であり当然北米は排除されてい る。そのイベロアメリカの牽引役が経済成長著しいブ ラジルである．米国と一線を画そらとする中南米の心 意気を感じさせる地域国際会議であった（主催はブラ ジル生物物理学会, アルゼンチン生物物理学会, ラテ ンアメリカ生物物理学連合).

\title{
World-wide Biophysics Now II. (1) Biophysics in the Developing Countries
} Kuniaki NAGAYAMA

Okazaki Institute for Integrative Bioscience, National Institutes of Natural Sciences 
この会議には4 日間の生物物理夏の学校が接続して おり，参加者の 8 割以上が $\mathrm{PhD}$ 院生を含む若手であっ た. 招待講演 64, ポスター 320, 総参加者は 400 を超 えていた。私が初日の開会講演を行ったがイベロアメ リカ以外から私以外 10 人以上が招かれていた。 しか もとの多くが夏の学校の講師となるといら高効率の運 営であった。こうしたすぐれた組織体制は今回の大会 委員長 Marcelo Morales（リオデジャネイロ連邦大学, 生物物理研究所）の指導性のゆえと思われる.

口頭発表は粒揃いであり，イベロアメリカからの発 表も質の高いものであった。 基調講演 8 , セッション は以下の 12 であった. Symposium I - Ion Channels and Transporters, Symposium II - Membrane Biophysics, Symposium III - Computational and Systems Biology, Symposium IV - Excitation-Contraction Coupling, Symposium V - Single Molecule and Nanoscale Biophysics, Symposium VI - LipidProtein Interactions, Symposium VII - Protein Biophysics, Symposium VIII - Molecular Bioenergetics and Dynamics, Symposium IX - Macromolecular Assemblies, Symposium X Epithelial Transport and Pumps, Symposium XI - Structural Proteomics, Folding and Drug Design, Symposium XII - Synaptic Transmission

南米から北米への頭脳流出を食い止めたいと大会委 員長 Morales が私に熱く語っていたのが印象に残る。

第 10 回生物物理学国際夏の学校 (2009年 9 月 19 日-10月 1 日, クロアチア)

東欧はなぜか生物物理がさかんで IUPAB 加盟国は 10 力国を数える. 30 年近い歴史をもつこの夏の学校 が東欧生物物理学隆盛の下支えをしたのだろらか。き わめて優秀な指導者 Ruder Boskovic 研究所（ザグレブ） の名誉教授 Greta Pifat の努力の賜物であろう.

私を含を 25 人の講師はそれぞれ3 日間の講義を受 けもち，導入部から最新の研究紹介までを行った。す ベてシニアの私が聞いてもワクワクする聴きごたえの ある分厚い講義であり，㛜選された 100 名の若手が熱 心にノートを取り，質問していた。1981年からほぼ 3 年ごとに開かれており 10 回目の今回は超分子の構 造と機能に焦点をあて以下の内容に沿った講義が連日 朝 8:30 から夜 7:30末で続いた。1）The structure and dynamics (Structure of proteins and their multidomain organization, Nucleic acids: from DNA structure to human genome, Supramolecular assemblies, Soft matter, Signal transduction, Dynamics of biosystems at different time-scales); 2) Major techniques in biophysics (diffraction and scattering techniques, magnetic resonance spectroscopies, fluorescence spectroscopy, mass spectrometry, microscopic techniques, single molecule spectroscopy, computational techniques in biophysics, infrared spectroscopy), 3) Bioinformatics (genomics and proteomics, macromolecular modelling) and 4) Biocomplexity in evolution.

アドリア海の避暑地ロビニでの短い滞在だったが, クロアチアの海洋自然美を味わらことができた．若者 はとても日本に関心が強く憧れもあり，講演のみなら ず私の日本の話を夜遅くまで聞いてくれた。

\section{まとめ}

クロアチアの夏の学校とブラジルのワークショップ は IUPAB から援助（クロアチア:9,000ドル，ブラジ ル:11,000ドル）されており, 今回の私への招待もそ らしたIUPABとの連携の一環であった. IUPABは 2009 年度この他にインド (9000ドル), ルーマニア (6000ドル)，ブルガリア（5000ドル）を支援してい る.これらもすぐれた若手教育として成功したと聞い て扣り，途上国に打ける生物物理学の未来に明るさを 見出した今回の講演旅行であった.

文 献

1）永山國昭（2007）生物物理 $\mathbf{4 7}, 66-67 \sim(2008)$ 生物物理 48 , 144-145.

\section{永山國昭（ながやま くにあき）}

自然科学研究機構岡崎統合バイオサイエンスセンター兼生理学研 究所教授

理学博士. 1973 年東京大学大学院理学系研究科満期退学, 74 年 理学博士. 同助教, 日本電子 (株) 生体計測学研究室長, 科学技 術振興事業団プロジェクト総括責任者, 東京大学教養学部教授, 生理学研究所教授を経て, 2001 年より現職.

研究内容: イメージングサイエンス, 電子線顕微鏡学, 生命の熱 力学的基礎論

連絡先: $\overline{7} 444-8787$ 愛知県岡崎市明大寺町東山 5-1

E-mail: nagayama@nips.ac.jp

URL: http://www.nips.ac.jp/dsm/ 